\title{
zon \\ PRINTED AND ELECTRONIC RESOURCES UTILIZATION BY STUDENTS OF BINYAMINUUSMAN POLYTECHNIC, HADEJIA, JIGAWA STATE, NIGERIA
}

\author{
Muhammad Bulama, Ibrahim Garba, Hassan Adamu, Alasan Usman \\ E- Mail Id: bulamabnw@yahoo.com \\ Library Unit, Binyaminu Usman Polytechnic, Hadejia, Jigawa State, Nigeria
}

\begin{abstract}
The study investigated the extent of whichprinited and electronicresources are being utilized by the students of Binyaminu Usman Polytechnic, Hadejia, Jigawa State, Nigeria.The study reveals that the respondents were aware about the availabilityof different type of information resources through orientation programme as well as class room lecture on the introduction on how to use the library. The study showed that traditional resources are more used such as print books, journals, projects, newspapers ,also, electronic resources like internet, e databases etc only $8 \%$ used non-print resources like compact disc(CD) read only memory (CD ROM). Survey research design was used in this study whose population consisted of all registered library users in the 2018/2019 academic session. Accidental sampling technique was used to select 400 respondents out of a total population of 2,667 registered users. Questionnaire was the instrument used for data collection. The data collected was analyzed using descriptive statistics (simple percentage) The study reveals that the students become aware of the library resources and services through the polytechnic effort of introducing library courses, orientation as well as directional signs within the polytechnic. The study further reported varying frequency of used as well as increase utilization as result of electronic resources provided. The major challenges identified are lack of information literacy skills, poor subscription of network. Some suggestions were outlines.
\end{abstract}

Keywords: Utilization, Printed Resources, Electronic Resources, Binyaminu Usman Polytechnic, Hadejia.

\section{INTRODUCTION}

Information resources are the container, vase, medium, or platform in which needed information is recorded for proper storage and dissemination of information. Generally, information resources could be of different types and formats, such as print, non -print and electronic, such as traditional print books, journals, dictionaries, e-books, ejournals, internet and other virtual environment. Information services are the services rendered to the clients to assist them in getting the right information in the right time and place. Such as selective dissemination of information (SDI) current awareness services (CAS) online public access catalogue (OPAC) etc.

In this regard, this study seek to investigate the extent of which students of Binyaminu Usman Polytechnic Hadejia utilized the information resources at their disposal. In this information age students undergoing training in any field need to be able to access and utilized information resources and services. Therefore, this study will assist students of the polytechnicto meet their present and anticipated information needs, this could be by enlighten them the basic information literacy skills to explore more during their academic work. Information literacy is the ability to find, evaluate and use information ethically.

\section{STATEMENT OF THE PROBLEM}

Information resources are materials, devices and equipment that contain written prints, soft (electronically) written voiced recorded, pictorial yoked with writing and the audio and video contain of information. The idea of undertaking this research arise as a result of the fact that researchers are biased towards university system, by neglecting other tertiary institutions such as colleges of education, polytechnics', monotechnic etc. Observation shows that despite the benefit of using the information resources and services towards the success of academic activities of the students, yet, most of the students were not aware about the availability and how to use information resources and services at their disposal and even beyond.The global trend in information service delivery is now characterized with fundamental shift from traditional information environment to an environment where emphasis is placed more on acquisition of e-resources such as e-books, e-journals as well as online databases. Kamba (2018) notes that libraries are changing dramatically by adopting new means of technology in all activities of print to eenvironment where variety of manual method, are replaced by computerized system which provides opportunity for online accessibility.

\section{RESEARCH OBJECTIVES}

DOI Number: https://doi.org/10.30780/IJTRS.V05.I04.003

pg. 17

Www.ijtrs.com

Www.ijtrs.org

Paper Id: IJTRS-V5-I4-015 


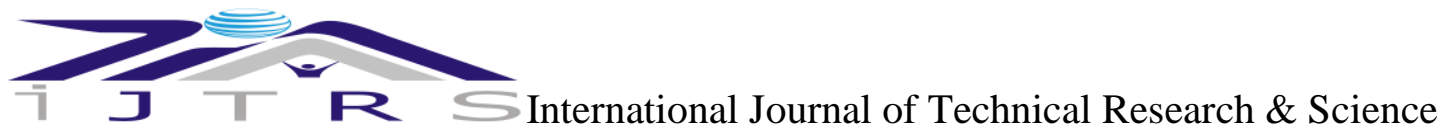

$>$ Identify the level of student's awareness on availability of different information resources and services in Binyaminu Usman Polytechnic, Hadejia.

$>$ Determine the extent ofwhich students of the polytechnic understudy utilized information resources and services.

$>$ Identify the challenges associated with utilization of information resources and services by the students in the polytechnic understudy.

\section{SIGNIFICANCE OF THE STUDY}

The overriding aims of polytechnic education is the promotion of technical and vocational education and training, technology transfer and skills development to enhance the socio-economic development of the country. Above all, the strategies in which information resources and services are being acquired, organized and disseminated. The study will assist the librarians of the polytechnic and sister institutions to modify theservices available to meet the immediate and future informationneeds of the students. Likewise, Jamil, Tariq and Jamil (2013) submits that library is a collection of an organized collection of published and unpublished books and audio-visual materials with aid of services of staff that is able to provide and interpret as acquired, to meet the educational, informational, and research needs of its users. In conclusion, the study will assist the management of the polytechnic to know the type of information resources and services to be provided for proper storage, processing, and dissemination of information to the various respective users.

\section{REVIEW OF RELATED LITERATURE}

The rapid change in technology has become the major cause of revolution in the field of library and information services from traditional information sources to e-resources, online databases and online information storage and retrieval etc. A study conducted byYebowaahms and Plockey (2017) emphasis that in moderntime, the content of libraries is not restricted to physical format. Such as books, magazines, or journals. Libraries are now shifting from traditional printed materials to the use of information and communication technology (ICT) and other electronic driven services. In other words, Nwokocha and Chima (2013) submit that information resources they are those materials, strategies, manipulations, apparatus, or consultation that help the researcher to enhance research and development.In a similar development, Ternenge and Kashimana (2019) in their study to find the type of electronic information resources such as e-journals, e-newspaper, online public access catalogue, compact disc read onlymemory, e-magazines, e-books, online data bases etc.

Based on the above findings for proper utilization of information to take place in Binyaminu Usman Polytechnicthe information resources and services collected should serve the mission and vision of the polytechnic, On the other hand, Egbunu and Usman (2013) on the availability and utilization of information resources and services by academic staff in the university Abuja indicated that availability of library resources wasfairly adequate and the library under-utilized. In this regard, the quality and quantity of information must be presented in both format print, non-print and electronic. The electronic resources are not a substitute to the traditional method of information delivery but to supplement it. TheLibrary Bill of Right (2019) digital resources allowed libraries significantly expand the scope of information available to users. Effective information searching is critical to students of Binyaminu Usman Polytechnic, Hadejia, moreover, the changing information needs of the students should be considered, information needs according to Wikipediathe free encyclopedia is often understood as an individual or group desired to locate and obtain information to satisfy a conscious or unconscious need. Saikia and Gohain (2013) study the use of library resources by the students of Kalyani the authors found that guidance in the use of library resources and services is necessary to help students meet their information needs out of the 200 questionnaires distributed among students and research scholars in Tezpur university to collect relevant data $32.07 \%$ (51) responded visited the central libraryevery day . it was found that $82.39 \%$ (131) users borrowed textbooks, $79.87 \%$ (127) consulted journals and $75.47 \%$ (120) read newspapers. Based on this library staff in Binyaminu Usman Polytechnic Hadejia should use their vast skills and experience to re-design the service delivery to attract students to be friends of the library.

\section{METHODOLOGY}

Descriptive survey research was use to collect data for this study. According to Joshua (2013) survey research design is where the purpose is to find the views, attitudes, or interest of a large population using a representative selection from such a population. Quantitative research methodology which is based on positivist paradigm denoting that the research is quantitative in nature which deals with figures and numbers in trying to identify the phenomena under investigation. Maiwada (2011) pointed out that quantitative research methodology means describing a phenomena quantitively in number or figures.

\section{PRESENTATION OF RESULTS}

DOI Number: https://doi.org/10.30780/IJTRS.V05.I04.003

pg. 18

$$
\begin{aligned}
& \text { www.ijtrs.com } \\
& \text { www.ijtrs.org }
\end{aligned}
$$


J $\square$ R 5 International Journal of Technical Research \& Science

The data on the level of awareness of the availability of information resources and services in Binyaminu Usman Polytechnic, Hadejia, is presented as follows:

Table-7.1 The Level of Awareness of Availability Information Resources by the Students in Binyaminu Usman Polytechnic, Hadejia, Jigawa State, Nigeria

\begin{tabular}{|c|c|c|}
\hline Available Options & Number of Respondents & \% \\
\hline Through a library staff & 31 & 33 \\
\hline During orientation programme & 132 & 14.25 \\
\hline Through student's handbook & 57 & 28.75 \\
\hline Through lectures about library & 115 & 16 \\
\hline Through directional signs & 65 & 100 \\
\hline Total & 400 & \\
\hline
\end{tabular}

The data on table 1 above shows the various means through which the respondents became aware of the availability of information resources and services in Binyaminu Usman Polytechnic, Hadejia. 132 students representing 33\% became aware through orientation programme they were able to attended. Also, 115 students representing $28.75 \%$ knew about the information resources / services through the lectures delivered by the library staff on the introduction of the use of library. 65 (16.25) through directional signs within the polytechnic premises, 57 (14.25) through students' handbook, insignificant numbers $7.75 \%$ through library staff.

Table-7.2 The Extent of Utilization of Library Information Resources and Services in Binyaminu Usman Polytechnic, Hadejia

\begin{tabular}{|c|c|c|}
\hline Frequency of use & Respondents & \% \\
\hline Daily & 73 & 18.25 \\
\hline Twice a week & 87 & 21.75 \\
\hline Monthly & 105 & 21.5 \\
\hline Quarterly & 86 & 12.25 \\
\hline Occasionally & 49 & $\mathbf{1 0 0}$ \\
\hline Total & $\mathbf{4 0 0}$ & \\
\hline
\end{tabular}

Table 7.2 indicated that $18.25 \%$ of the respondents used theinformation resources / services in the library on daily basis. $21.75 \%$ used the library twice a week, $26.25 \%$ used the library monthly, $21.5 \%$ used the library quarterly. Likewise, 12.25 used the information resources/services quarterly. Therefore, other alternatives should be device to attract the student to visit the library regularly like current awareness services, selective dessimination of information.

Table 7.3 Showing the Rationale for Using the Library

\begin{tabular}{|l|l|l|l|l|l|}
\hline Reason for Usage & Resp. & $\mathbf{\%}$ & Preferred Materials & Resp & \% \\
\hline Current Awareness & 32 & 8 & Print Materials & 224 & 56 \\
\hline Social Networking & 122 & 30.5 & Non-print Materials & 32 & 8 \\
\hline Assignment & 112 & 28 & Electronic Materials & 44 & 36 \\
\hline Examination & 122 & 30.5 & Pleasure & 12 & 3 \\
\hline Total & $\mathbf{4 0 0}$ & $\mathbf{1 0 0}$ & Total & $\mathbf{4 0 0}$ & $\mathbf{1 0 0}$ \\
\hline
\end{tabular}

DOI Number: https://doi.org/10.30780/IJTRS.V05.I04.003

pg. 19

Www.ijtrs.com

Www.ijtrs.org 
7 ᄀ $\mathrm{R} S$ International Journal of Technical Research \& Science

Different reasons were given by the respondents for using the information resources and services in the library as shown in table 3 above $30.5 \%$ of the respondents use the library for social networking and during examination respectively. $28 \%$ when they have assignment, but only $3 \%$ percent used the library for pleasure. Similarly, $56 \%$ used the library to consult print materials, $36 \%$ used the available electronic resources in the library, while only $8 \%$ percent used the non-print materials for their academic activities. Therefore, as indicated both the printed and electronic resourcesare significantly utilized as such latest information ressources need to be collected, stored and disseminated and proper guidance from the polytechnic library staff to facilitate uses.

Table-7.4 Showing the Various Challenges Encountered in Using the Information Resources and Services

\begin{tabular}{|c|c|c|}
\hline Available options & Respondents & \% \\
\hline Lack of knowledge of relevant information & 192 & $\mathbf{0}$ \\
\hline Unavailability of information resources & 71.75 & 16.5 \\
\hline Lack of computer knowledge & 66 & $\mathbf{0}$ \\
\hline Inadequate number of computers & $\mathbf{0}$ & $\mathbf{0}$ \\
\hline Irregular power supply & $\mathbf{0}$ & 17.75 \\
\hline Poor internet services & 71 & 16 \\
\hline Lack of proper maintenance & 64 & $\mathbf{1 0 0}$ \\
\hline Total & $\mathbf{4 0 0}$ & $\mathbf{0}$ \\
\hline
\end{tabular}

The table shows that the major shortcomings are lack of knowledge of relevant information by the students Information literacy skills can facilitate when using any type of information. As, 17.75 indicated poor internet services which is the major ingredient for using e-resources.

\section{RECOMMENDATIONS}

$>$ Information literacy skills should be introduced to enable students to find, evaluate and use information efficiently.

$>$ More sources of educating the students to be aware about the availability of different information resources and services and the essence of using the library should be provided.

$>$ Sufficient funds should be allocated to the library in order ensure sustainability of the internet subscription as well as maintenance services.

$>$ Practical should be given more priority on the course taught introduction of the use of library. So that students can quickly access the relevant information resources and services.

\section{REFERENCE}

[1] Egbunu, J.A.\& Usman, A. (2013) Availability and utilization of information resources and services by academic staff in university Abuja. African journal online vol. 10 (2)

[2] http://en.wikipeadia.org /wiki/information-needs, access 04/10/2019

[3] Jamil, M., Tariq, R., \& Jamil, S. (2013) Library utilization by teachers and students. Bulletin of education research vol. 35 (2)

[4] Joshua, O. (2013) The essentials of research methodology and statistics in education. Jigbik publishers, Bauchi State, Nigeria.

[5] Kamba, M.A. (2018) Analysis of current user services model in Nigerian libraries paper presented at a workshop organized by Librarians Registration Council of Nigeria (LRCN) At Bayero University Kano, $21^{\text {st }}$ 25 may, 2018.

[6] Maiwada, D. A. (2011) Statistics in educational research an overview. Faculty of education research, seminars committee BUK. Ahmadu Bello University press limited.

[7] Nwokocha, U. \& Chimah, (2013) Information resources retrieval and utilization for effective research institutions. Asian journal of humanities and social sciences vol. 1 (3).

[8] Saikia, M. \& Gohain, A. (2013) Use and users' satisfaction in library resources and services: A study in Tezpur University India. International journal of library and information science. 5 (6)

[9] Ternenge, S. T. \& Kashimana, F. (2019) Availability, accessibility, anduse of electronicinformationresources for research by students in Francis Sulemana Idachaba Library University of Makurdi

[10] Yebowaahms, F. \& Plockey, F.D. (2017) Awareness and use of electronic resources in university for development studies libraries. 